\title{
The Significance of English Grammar to Middle School Students in China
}

\author{
Shengmei Wang \\ School of Foreign Languages, Huaiyin Normal University, Huai'an Jiangsu, 223300, China. \\ Email: hiwangshengmei@163.com
}

\begin{abstract}
In the last few years the pendulum of grammar instruction seems to be on the return swing both in the USA and the UK because of public pressure for standards and testing. The reasons for grammar instruction and different foreign language teaching methods are explored in this paper. Some experiments are followed up to demonstrate grammar instruction is vital in EFL learning and teaching in China
\end{abstract}

Index Terms - grammar instruction, necessity, controversy, the case of China

\section{INTRODUCTION}

With the progress of globalization in the economy and in society, it is essential for Chinese students to acquire communication skills in English, which has become a common international language, in order for living in the $21 \mathrm{st}$ century. This has become an extremely important issue both in terms of the future of Chinese children and the further development of China as a nation. But over the last two decades, the summary of English education in China most often repeated by students and teachers and parents is that "Although we study English for all of ten years we still cannot speak it." People became frustrated about not being able to speak as much and fast as they wished. They decided to blame the traditional Grammar Translation method. To improve the situation China has adopted, experimented, discarded, and mixed different methodologies of English teaching over decades, the current trend is actually a mixture of several methods. One thing is certain; less grammar is taught, at least less explicit grammar instruction.

However, after a brief review of the history of language instruction, it's found that grammar has always been playing a role in foreign language teaching and learning. This may probably be one of the reasons leading to the debates of teaching grammar. The debates result in fresh cognition of grammar: it is very important in that not only does it help improve learners writing, but also it helps learners do better in reading comprehension and listening alike; more significantly, the problem of how to teach grammar has been raised. The finding from the survey is that middle school students from China believe that grammar is very important and necessary. There are several reasons for its importance and necessity, one of which is that they have few opportunities and little time to get enough input inside and outside the class.

\section{THE NECESSITY OF GRAMMAR INSTRUCTION}

Does it matter whether schools teach grammar? For Frank Palmer(1972), the central part of a language is its grammar, and this should be of vital interest to any intelligent educated person. If it has not been of such interest, then the fault must be in the failure to recognize its importance within this essentially human activity, language. It is true that learning particular grammatical distinctions requires a great deal of time even for the most skilled learners. Thus, one important question is whether it is possible to accelerate students' natural learning of grammar through instruction. Research findings can be brought to bear on this question from a variety of sources, for example, Larsen-Freeman \& Long's(1991) Second Language Acquisition and Research. With regard to whether instruction can help learners acquire grammar they would not have learned on their own, some researches, although not unequivocal, point to the value of form-focused instruction to improve learners' accuracy over what normally transpires when there is no focus on form. Larsen-Freeman(2000) offers details in his Form, Meaning and Use. Besides, in her thesis for masters' degree “ The Importance of Grammar in Reading", Tang Jingjing(2002) argues that there is beneficial effect of grammar instruction on the student's reading. Explicit instruction is an important part of grammar teaching and is easier if the pupils already have some understanding of how their first language works.

Explicit awareness of grammatical structure probably helps children to expand their competence to include the many grammatical patterns which are needed in adult life but not found in children's casual conversation and a shared metalanguage allows teachers and pupils to communicate about their performance and to explore complex links such as those between grammatical structures and genres.

The importance of grammar is also due to the fact that it is because of grammar of the language that makes it possible for us to talk about language. Grammar names the types of words and word groups that make up sentences not only in English but also in any language. As human beings, we can put sentences together even as children--we can all do grammar. But to be able to talk about how sentences are built, about the types of words and word groups that make up sentences--that is to know about grammar. And knowing about grammar also helps us understand what makes sentences 
and paragraphs clear and interesting and precise. Grammar can be part of literature discussions when we and our students closely read the sentences in poetry and stories. And to know about grammar means finding out that all languages and all dialects follow grammatical patterns.

On all accounts, Grammar is the first liberal art. The study of grammar has two goals. Firstly, it preserves and perfects understanding of the great literature of the past and it contributes to eloquent self-expression. Secondly, questioning the value of grammar is like asking whether farmers should know the names of their crops and animals. Putting it another way, given that words constitute the essence of the intellectual life, a scholar or student who doesn't know grammar, for instance, the parts of speech, is like a surgeon who doesn't know the parts of the body.

\section{THEORETICAL APPROACHES TO GRAMMAR TEACHING}

Foreign language teaching has a history of hundreds of years (Modern foreign language teaching dates from 17th century.), if not thousands of years (According to the recorded historical materials, the earliest foreign language teaching dates back to 300 BC when the Romans began to learn Greek.) (Hang 2000). During the long period of foreign language teaching, it is the recognition of changes in the kind of proficiency that learners need that leads to changes in language teaching methods. Of all the methods applied in the foreign language teaching, the most influential ones are the Grammar-Translation Method, the Situational Language Teaching, the Audiolingual Method and the Communicative Language Teaching Method. Grammar in these different influential methods plays a different role. In other words, though these different methods have different attitudes towards grammar, in common they all consider it part of language teaching.

\section{A. Grammar in the Grammar-translation Method}

The principal characteristics of the Grammar-Translation Method are these: the goal of foreign language learning is to learn a language in order to read its literature, so reading and writing are the major focus. Grammar-Translation is a way of studying a language that approaches the language first through detailed analysis of its grammar rules, followed by application of this knowledge to the task of translating sentences and texts into and out of the target language. It hence views language learning as consisting of little more than memorizing rules and facts in order to understand and manipulate the morphology and syntax of the foreign language. Grammar is taught deductively--that is, by the representation and study of grammar rules, which are then practiced through translation exercises. In most Grammar-Translation texts, a syllabus is followed by the sequencing of grammar points throughout a text, and there is an attempt to teach grammar in an organized and systematic way. In one word, grammar is essential in foreign language teaching. Grammar-Translation dominated foreign language teaching in Europe from the ancient days to the 1940s. Although the Grammar-Translation Method often creates frustration for students, it makes few demands on teachers. It is still widely used in situations where understanding literary texts is the primary focus of foreign language study and there is little need for a speaking knowledge of the language. Contemporary texts for the teaching of foreign languages at college level often reflect Grammar-Translation principles. These texts are frequently the products of people trained in literature rather than in spoken language. So it is true to say that the Grammar-Translation Method is still widely practiced in modified form in some parts of the world today (Richards 1986).

\section{B. Grammar in the Situational Language Teaching}

Situational Language Teaching adopts an inductive approach to the teaching of grammar. The meaning of the structures is not to be given through explanation in either the native tongue or the target language but is to be induced from the way the form is used in the situation. New language points are practiced situationally. The main characteristic of the approach is that items of grammar are graded following the principle that simple forms should be taught before the complex ones. Reading and writing are introduced once a sufficient grammatical basis is established. Harold Palmer, one of the two leaders of Situational Language Teaching, the other being A. S. Hornby, emphasized the problems of grammar for the foreign learners in his writing (Richards 1986). Much of his work was directed toward developing classroom procedures suited to teaching basic grammatical patterns through an oral approach. He viewed grammar as the underlying sentence patterns of the spoken language. Accuracy in grammar is regarded as crucial. The syllabus in Situational Language Teaching is a structural one which is a list of the basic structures and sentence patterns of English. The textbook contains tightly organized lessons planned around different grammatical structures. The visual element together with a carefully graded grammatical syllabus is a crucial aspect of Situational Language Teaching.

\section{Grammar in the Audiolingual Method}

The Audiolingual Method is the result of combination of structural linguistic theory, contrastive analysis, aural-oral procedures and behaviorist psychology. Language is viewed as a system of structurally related elements for the encoding of meaning, the elements being phonemes, morphemes, words, structures, and sentence types. Linguistic levels are thought of as system within system--that is, as being pyramidally structured; phonemic system leads to morphemic system, and this in turn leads to the higher-level systems of phrases, clauses, and sentences. Learning a language, it is assumed, entails mastering the elements or building blocks of the language and learning the rules by which these elements are combined, from phoneme to morpheme to word to phrase to sentence. The structure is what is 
important and unique about a language, so early practice should focus on mastery of phonological and grammatical structures. Dialogues and drills form the basis of audiolingual classroom practice. After a dialogue has been presented and memorized, specific grammatical patterns in the dialogue are selected and become the focus of various kinds of drill and pattern-practice exercises.

\section{Grammar in the Communicative Language Teaching Method}

Since the mid-1970s the scope of Communicative Language Teaching has expanded. For some linguists and language teaching specialists, Communicative Language Teaching means little more than an integration of grammatical and functional teaching. Littlewood(1995) states "One of the most characteristic features of communicative language teaching is that it pays systematic attention to functional as well as structural aspects of language." In Hymes's view, a person who acquires communicative competence acquires first both knowledge and ability for language use with respect to whether or to what degree something is formally possible (Hymes 1972). A more recent but related analysis of communicative competence is found in Canale and Swain's(1980) Theoretical Basis of Communication Approaches to Second Language Teaching and Testing, in which four dimensions of communicative competence are identified: grammatical competence, sociolinguistic competence, discourse competence, and strategic competence. Grammatical competence refers to what Chomsky calls linguistic competence and what Hymes intends by what is "formally possible."

We can see the shape of grammar in all these influential foreign language teaching methodologies. Whether it is taught deductively or inductively, it attracts the attention of more and more researchers and experts who carried out researches to test the value of grammar teaching. However, the results they obtained were quite different or even opposite. This resulted in the debates of teaching grammar.

\section{THE CONTROVERSY OF GRAMMAR TEACHING}

According to Mulroy(2003), "The value of grammar was never challenged" until our day. Does training in "formal grammar" improve a student's ability to write? At one time it was taken for granted that the answer was yes, so students were taught grammatical analysis as part of the effort to improve their writing. However, when educational researchers sought evidence for the expected effects, the results were negative; for example, one of the classic experiments concluded: "It seems safe to infer that the study of English grammar had a negligible or even harmful effect upon the correctness of students' writing in the early part of the five secondary schools." (Harris 1962) A number of studies in the 60s and 70s have since been accepted as classic support for the view that grammar teaching does nothing for student's writing. By the late 60s the dominant view in both the UK and the USA, and possibly throughout the English-speaking world, was that "most children cannot learn grammar and ... even to those who can it is of little value." (Thompson 1969) No doubt this view fitted the spirit of the times both in English teaching (where grammar was seen as a shackle on children's imagination) and in linguistics (where Chomsky was arguing that grammatical competence develops naturally according to an innate programme, so teaching is simply irrelevant).

Since then, grammar has played a controversial role in second and foreign language teaching for decades. In the United States, the "Great Grammar Debate" lasted almost three decades. There are currently two extreme positions in English as a second language (ESL) and English as a foreign language (EFL) concerning the teaching of English grammar. At one extreme, the earliest research questioning the value of grammar teaching found that it was simply a waste of time in the sense that most children could not apply any of the categories even after many years of teaching (Hudson 1998). Methodologists such as Krashen and Terrell(1983) tell us in their Natural Approach not to teach grammar explicitly and not to correct any learner's errors. Influenced by their viewpoint of grammar, some teachers adamantly insist that teaching formal grammar is useless and even harmful. The anti-grammar tide reached its peak in November 1985, when the National Council of Teachers of English (NCTE) passed a resolution against the use of isolated grammar and usage exercises not supported by theory and research.

The objection to grammar teaching is clearly fundamental if it is true, but, at the other extreme, there are others who swear just the opposite. The proponents of audio-lingualism (Lado 1964) and the methodologists such as Gattegno(1976) argue that we must make grammar the core of our language instruction and that we must correct all student errors. Most research has found that, when well taught, any kind of grammar (traditional or modern) can be learned by most school children at least at secondary level (Elley 1994; Elley et al 1975; Herriman 1994; Kennedy and Larson 1969; Tomlinson 1994) and in some cases at primary level, one example being Gale' (1967) experiment of fifth-graders. Hudson's(1998) international survey showed that grammatical analysis is regularly taught in some countries to children as young as six or seven, and the evidence from developmental psychology is that metalinguistic awareness starts to develop naturally between 5 and 7 years .

Very little research in support of teaching grammar appeared since the flurry in the 60s and 70s, and the profession settled into a period in which the question was largely ignored. So was the teaching of grammar. This reflects very general attitude changes in education and more generally throughout society. In the last few years, however, that situation has changed significantly in both the UK and the USA, and the pendulum seems to be on the return swing. Public pressure for standards and testing has brought grammar back into many classrooms and revived the debate about how to teach it. NCTE has accepted a new Assembly, the Assembly for the Teaching of English Grammar, and the 
editors of many NCTE publications are actively seeking articles on what and how to teach grammar (Celce-Murica 1985).

We should not go to extremes. The fact is that grammar -- both as a description of language structures and as a standard of verbal etiquette -- still plays a big part in what many teachers, administrators, and parents consider to be basic literacy. Grammar can't be separated from the language, so the question more appropriately asked is how best to incorporate it into language instruction. Therefore, there is now much more enthusiasm in some educational circles for the idea that conscious grammar (resulting from formal teaching) could have the useful benefit of improving writing, and reading. In the USA this is apparently to be seen in freshman composition circles from Mccleary's(1995) Difficulty of Grammar and to a limited extent in the whole English approach to School English Teaching in Context by Weaver(1996), but in the UK it is one of the main pillars of the newly introduced National Literacy Strategy and the National Curriculum for English. These government directives apply to all state-run schools in England, primary and secondary, and prescribe in some detail both content and methods. The prescriptions are by no means bland commonplaces; on the contrary, they are an attempt to change current practice, and nowhere more so than by reintroducing the teaching of grammar. The 'Great Grammar Debate' in the United States leads to more precise questions about issues that teachers and researchers need to consider: what grammar should be taught; when it should be taught; and, the most important, how it should be taught.

\section{GRAMMAR INSTRUCTION IN CHINA}

Unlike L1 acquisition, L2 has to be taught. Outside a community where a L1is spoken as a native language, without being taught, you don't learn to speak, read, and write a foreign language. You may be able to exchange simple greetings and express emotions using short phrases, but without a good grasp of sentence construction, you most likely end up producing sentences and utterances that at best mislead listeners. As China became more and more enthusiastic about learning English, people became frustrated about not being able to speak as much and fast as they wished. They decided to criticize the traditional Grammar Translation method. Unexceptionally, grammar instruction experiences the similar ups and downs in China.

It is clear that the mention of the word "grammar" sends chills up many students' spines. Students also feel that specific types of exercises and/or activities are either useful or not useful when learning grammar. While instructors differ greatly in their opinions on the importance of grammar study in language teaching and even more so in their approaches to teaching grammar. Students do not always share the instructor's view of the role of grammar in their language learning. How do students feel about studying grammar when learning a language? How important is it to them? How do they go about studying it? What kinds of exercises and activities help them in their acquisition of grammar?

During her career as an EFL instructor both at middle school and college, she has always had an impression that those with good grammar do well in English proficiency tests and entrance exams. They write better and their reading ability is more accurate. When they speak the utterances are in more complete sentences with fewer grammatical errors. Their listening performance is often superior.

In attempting to have a comprehensive perspective of the role of grammar in language study, the author decided to do some experiments to confirm her impression. The purpose of Survey 1 is to investigate the attitudes and perceptions of students learning English in Chinese context foreign language learning. The purpose of Survey 2 is to show and college entrance exams and CET require grammar recognition.

\section{A. Students'Attitudes and Perceptions}

To understand what EFL students think about EGI and to explore the factors that influenced those attitudes and perceptions, the author conducted a pilot study in Huai'an Middle School (a key middle school in Jiangsu Province) to examine the attitudes and perceptions of Chinese middle school students toward EGI in the fall of 2005: How important is learning the basics of grammar for students to learn English well? Out of the 30 students who participated in the study, 23 of them said that they liked EGI because they believed that it would enable them to speak and write the English language correctly. In the spring semester of 2007, the author surveyed 298 students from six different classes of this same key middle school, two Senior One classes and two Senior Two classes and two Senior Three classes. The survey is based on a small-scale attempt to find the answer.

STUDENTS' ATTITUDES TO GRAMMAR

\begin{tabular}{|c|c|c|}
\hline Response & Number & Percent \\
\hline 1 Absolutely essential & 183 & $61.4 \%$ \\
\hline 2 Important but not essential & 70 & $24 \%$ \\
\hline 3 Depends on the individual needs and talent level & 12 & $4 \%$ \\
\hline 4 Not important & 4 & $1 \%$ \\
\hline 5 I have not opinion on this issue & 29 & $10 \%$ \\
\hline \multicolumn{2}{|c|}{ Total number of responses: 298 } \\
\hline
\end{tabular}




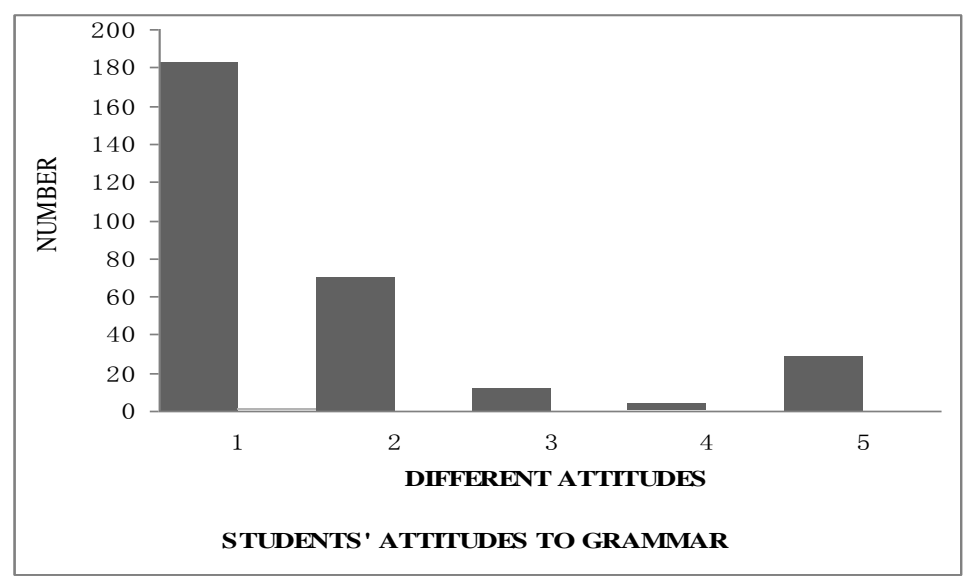

The table and chart above are the findings. While these responses may be interesting as a profile of these classes and their attitudes toward grammar study, they may also have some implications for the classroom English instruction. It is clear that students feel that grammar acquisition is important. Though they don't always like it, they recognize that it is necessary. Researchers studying students' attitudes toward grammar study recommend that teachers survey their own students as to their beliefs with regard to this topic. This suggestion is wholeheartedly seconded by the author.

\section{B. Correlation between Grammar Recognition and Test Scores}

To explore relation between grammar knowledge of the test takers and their scores, in 2009 the author conducted a study in Class 1 Grade 2008 in the School of Physics and Electronic Electrical Engineering in Huaiyin Normal University (a local university in Jiangsu Province). Out of 23 students 13 passed December 2008 CET-4, the first time they took CET-4. So the students were divided in two groups(CET-4 holders and non-CET-4 holders). They were given an error-correction test.(See Appendix) The test is focused on grammar points to see the students' understanding of word order rules, tense awareness, passive vs. active voices, how to pick correct conjunctions, and other aspects of English grammar. It is specifically not meant to measure general aspects of competence such as speaking and listening. At the same time, as will be seen, these points of grammar are not meaningless rules, abstract ideas, or obsolete prescriptive grammar. Rather, they are crucial points for Chinese EFL learners in reading, writing and speaking English. Not just any kind of English, but academically and globally acceptable English.

The students' scores of the test and their corresponding scores of university entrance exam(HPS is 120) and CET-4(HPS is 710) are compared in the chart below.

TABLE 1

THE CET-4 CERFIFICAE HOLDERS

\begin{tabular}{|c|c|c|c|}
\hline Student number & Error correction out of 10 & Score in the entrance exam & Score in CET-4 \\
\hline 2 & 7 & 93 & 492 \\
\hline 7 & 6 & 82 & 478 \\
\hline 8 & 8 & 92 & 510 \\
\hline 10 & 6 & 88 & 431 \\
\hline 11 & 9 & 100 & 592 \\
\hline 12 & 8 & 97 & 514 \\
\hline 15 & 10 & 104 & 545 \\
\hline 16 & 7 & 87 & 454 \\
\hline 18 & 9 & 93 & 495 \\
\hline 20 & 5 & 83 & 446 \\
\hline 21 & 7 & 105 & 459 \\
\hline 22 & 10 & 101 & 532 \\
\hline 23 & 8 & 92 & 510 \\
\hline average & 7.7 & 93.6 & 496.8 \\
\hline
\end{tabular}

TABLE 2

NON-CET-4 CERTIFICATE HOLDERS

\begin{tabular}{|c|c|c|c|}
\hline Student number & Error correction out of 10 & Score in the entrance exam & Score in CET-4 \\
\hline 1 & 2 & 72 & 380 \\
\hline 3 & 4 & 85 & 386 \\
\hline 4 & 2 & 85 & 390 \\
\hline 5 & 1 & 71 & 370 \\
\hline 6 & 6 & 83 & 402 \\
\hline 9 & 4 & 75 & 421 \\
\hline 13 & 7 & 85 & 374 \\
\hline 14 & 6 & 75 & 413 \\
\hline 17 & 2 & 78 & 381 \\
\hline 19 & 5 & 83 & 416 \\
\hline average & 3.9 & 79.2 & 393.3 \\
\hline
\end{tabular}


University entrance exams play a vital role in EFL in China and the Chinese general public are very keen on the scores of CET(College English Test). CET is kind of English proficiency tests to measure students' overall English skills. Among them the focus is on reading and listening. This can be judged by the amount of reading and listening in the test, which occupies $70 \%$ of the whole test. It never asks grammar questions and it looks like grammar doesn't play an important part in CET, but in reality as the charts 1 and 2 above show that the CET-4 certificate holders did significantly better in the grammar test. After analyzing the results it became clear that there is an obvious relation between grammar knowledge of the test takers and their scores -- grammar recognition helps in English proficiency tests and college entrance exams, that is, the more knowledgeable in grammar they are, the higher the scores.

The responses of the students in this survey and the results of the tests may have been influenced by a number of factors including time constraints, the teaching style of their instructors in, their own learning style, the emphasis placed on grammar in the language curriculum, among many others. Though this study was by no means scientific, it can provide some interesting insights into grammar instruction and the way Chinese middle school students approach grammar in their language study.

\section{CONCLUSION}

To sum up, Grammar as the law of language is essential to language. The relationship between grammar teaching and language skill cultivation is not one of contradiction but one of co-existence and mutual dependence, for language knowledge is the foundation of language skills and language skills are not only the means for communication but also the means for acquiring language knowledge. The nature of grammar determines that grammar teaching is necessary. Without a firm knowledge of grammar in the target language, learners cannot produce meaningful sentences. They risk being misunderstood and making crucial mistakes in communication both oral and written. This is especially true when the mother tongue and the target language are significantly different in grammar and structures.

\section{APPENDIX ERROR CORRECTION TEST}

1. Many students in our class prefer playing to study math.

2. She wants to something cold to drink for her breakfast.

3. I was in Hawaii during I was on vacation last summer.

4. This job can certainly do by the end of this week.

5. He has often visited this museum when he was a child.

6. Have you been seen the new dress Mary bought on the Elm Street yet?

7. Jane is one of most diligent student in our school.

8. Do I usually look like happy when I'm with you?

9. Tell me what are you thinking right now.

10. She was heard to singing that old Irish folksong.

\section{REFERENCES}

[1] Canale, M. and Swain, M. (1980).Theoretical Basis of Communication Approaches to Second Language Teaching and Testing. Journal of Applied Linguistic 1/1.

[2] Celce-Murica.(1985). Making Informed Decisions about the Role of Grammar in Language Teaching. TESOL Newsletters 9. Feb1, 3-4.

[3] Elley, W. B. (1994).Grammar Teaching and Language Skill. Encyclopedia of Language and Linguistics. Ed. R. Asher. Oxford: Pergamon. 1468-71

[4] Elley, W. B., I. H. Barham, H. Lamb, and M. Wyllie.(1975). The Role of Grammar in a Secondary School Curriculum. New Zealand Council for Educational Studies.10, 26-41.

[5] Gale, Irma Frances.(1967). An Experimental Study of Two Fifth-Grade Language-arts Programs. An Analysis of the Writing of Children Taught Linguistic Grammars Compared to Those Taught Traditional Grammar. PhD thesis, Ann Arbor.

[6] Gattegno, C. (1976). The Common Sense of Teaching Foreign Language. New York: Educational Solutions.

[7] Baotong Hang.(2000). English, Teach It Better. Shanghai: East China Normal University Press.

[8] Harris, R. J.(1962). An Experimental Inquiry into the Functions and Value of Formal Grammar in the Teaching of English. With Special Reference to the Teaching of Correct Written English to Children Aged Twelve to Fourteen. PhD thesis, University of London.

[9] Herriman, M. (1994).Literacy and Metalinguistic Awareness. Encyclopedia of Language and Linguistics. Ed. R. Asher. Oxford: Pergamon. 2243-6.

[10] Hudson, Richard. (1998).Is Grammar Teachable? English, 2, 11-14;82-3.

[11] Hymes, D. (1972).Communicative Competence. In J.B Pride and J. Halmer (ed.). Sociolinguistics, Harmondsworth: Penguin.

[12] Kennedy, L. D. \& A. D. Larson. (1969). The Influence of Structural and Traditional Grammatical Instruction upon Language Perception and Writing Ability. Illinois School Research 5.2, 31-36.

[13] Krashen, S. D. \& Terrell, T. (1983).The Natural Approach: Language Acquisition in the Classroom. Oxford: Pergamon.

[14] Larsen-Freeman, D. \& Long, M. (1991). An Introduction to Second Language Acquisition and Research. London: Longman.

[15] Lado, R.(1964). Language Teaching: A Scientific Approach. New York: McGraw-Hill.

[16] Larsen-Freeman, D.(2000). Grammar Dimensions: Form, Meaning and Use. Boston: Heinle \& Heinle. 
[17] Littlewood, William. (1995).Communicative Language Teaching. Beijing: Foreign Language Teaching and Research Press. 2000.

[18] Mccleary, Bill.(1995). Grammar Making a Comeback in Composition Teaching. Composition Chronicle: Newsletter for Writing Teachers 8.6, 1-4.

[19] Mulroy, David. (2003).The War against Grammar. Portsmouth, NH: Heinemann.

[20] Palmer, Frank.(1972). Grammar. Harmondsworth: Penguin Books Ltd.

[21] Richards, Jack C. (1986).Approaches and Methods in Language Teaching. Cambridge: Cambridge University Press.

[22] Jingjing Tang. (2002). The Importance of Grammar in Reading. Master Degree thesis, University of Central China Normal Press.

[23] Tomlinson, D.(1994). Errors in the Research into the Effectiveness of Grammar Teaching. English in Education. 28 , 2-26.

[24] Thompson, D.( 1969). Directions in the Teaching of English. Cambridge: Cambridge University Press.

[25] Weaver, Constance. (1996).Teaching Grammar in Context. Portsmouth, NH: Heinemann.

Shengmei Wang was born in Huaian, China in 1966. She received her BA. degree in linguistics from Yangzhou University, China in 1988 .

She was previously a teacher in Huai'an Middle School and is currently a lecturer in the School of Foreign Languages, Huaiyin Normal University, Huai'an, China. Her research interests include applied linguistics, language and culture and syntax. 